\title{
Ureter Urothelial Papilloma
}

National Cancer Institute

\section{Source}

National Cancer Institute. Ureter Urothelial Papilloma. NCI Thesaurus. Code C6160.

A benign epithelial neoplasm that produces visible warty projections from the epithelial surface of the ureter. 